\title{
Gendering the Arab Spring ${ }^{1}$
}

\author{
Nadje Al-Ali \\ University of London, UK \\ Email: N.S.Al-Ali@soas.ac.uk
}

\begin{abstract}
The article discusses the gendered implications of recent political developments in the region. It argues that women and gender are key to both revolutionary and counterrevolutionary processes and developments and not marginal to them. It explores the significance of women's involvement, the historical context of women's political participation and marginalization in political transition. Theoretically, developments in the region point to the centrality of women and gender when it comes to constructing and controlling communities, be they ethnic, religious or political; the significance of the state in reproducing, maintaining and challenging prevailing gender regimes, ideologies, discourses and relations; the instrumentalization of women's bodies and sexualities in regulating and controlling citizens and members of communities; the prevalence of genderbased violence; the historically and cross-culturally predominant construction of women as second-class citizens; the relationship between militarization and a militarized masculinity that privileges authoritarianism, social hierarchies and tries to marginalize and control not only women but also non-normative men.
\end{abstract}

Keywords

gender, women's rights, revolution, counter-revolution

It has almost been impossible over the last few months to keep up with political developments in the Middle East: small scale demonstrations, and mass protests; revolutionary processes that not only involve the political sphere but that have also touched the social fabric; the ousting of several dictators; the brutal crackdown and killing of peaceful protesters; armed struggles, NATO involvement and wider debates about international intervention; not to mention various forms of counter-revolutionary backlash and the struggles of old regimes to hold on to power.

${ }^{1}$ This contribution is based on and developed from my inaugural lecture entitled 'On Not Travelling Lightly: Transnational Feminist Journeys to and from the Middle East', 18 May 2011, SOAS, University of London.

(C) Koninklijke Brill NV, Leiden, 2012

DOI $10.1163 / 187398612 X 624346$ 
In the initial phase of these rapid changes and developments, I was frequently asked: 'Where are the women?' The first images we saw of protests in Tunisia and Egypt were largely of men. Later on the images and the coverage of the protests changed and it became clear that women were involved at all levels. Individual women were given particular media attention: in Egypt, Asma Mahfouz became known by many as the leader of the revolution' after posting an online video calling young people to demonstrate en masse, helping to spark the protests that forced President Hosni Mubarak's resignation. In Bahrain, political activist Munira Fakhro played a leading role as an organizer and spokesperson for the Pearl Square demonstrations, demanding government reform and building a movement that was 'not Sunni, not Shia, but Bahraini'. In Yemen, human rights activist and journalist Tawakul Karman has protested nonviolently outside Sanaa University every Tuesday since May 2007, demanding that President Ali Abdullah Saleh step down from power.

Yet it was not just individual women - women participated side by side with men in the protests across the region. In light of western media representations and widespread perceptions among the public in western countries that women in the region did not just appear on the scene in 2011, we should clarify: for decades they had been active members in trade unions, political opposition parties and more informal networks and organizations that were all instrumental in the recent political developments. Women have been very much involved in the virtual communities of bloggers and Facebook users. And during the height of the actual protests to oust Ben Ali and Mubarak, women of all generations and social classes were on the streets in large numbers. Notably in places like Tahrir Square in Cairo, where men and women mingled for weeks in extremely crowded and volatile situations, many Egyptian women reported that they had never felt as safe and been treated as respectfully as during the time of these protests.

Without doubt, it has been easier for women to participate in politics in Egypt, where the protest movement had initially taken an explicitly nonviolent character - silmiya - and where there exists a long history of largescale women's political participation. Indeed, in Egypt and also in Iran, which to my mind should not be left out in current discussions about people's power and resistance, women activists have been spearheading civic rights, democracy and human rights movements in the context of their women's rights struggles. My own work on the Egyptian women's movement in the mid-199os revealed that women's rights activists were engaged in contestations with the state about the shaping of gender policies as well 
as wider issues of citizenship and social justice. To varying degrees, Egyptian women have engaged for a long time in grassroots activism and have aspired to find non-hierarchical ways of organizing, thereby engaging in the process of democratization.

Yet, even in the more socially conservative countries like Yemen, Libya, Bahrain and Syria - and they are all very different from each other-we find that women have increasingly pushed the boundaries of what is socially acceptable when joining the protests and making their own gender-specific demands, in addition to joining in the wider calls for reforms, democratization, an end to corruption, political transparency and human rights.

It is not surprising that revolutionary processes should open up social and political spaces for women. History is full of comparable examples around the world. If we speak of the Middle East, the most commonly cited examples are the Egyptian anti-colonial and independence movement at the turn of the twentieth century that gave rise to the Egyptian women's movement; the Algerian war of independence in the time of French colonialism; and the Palestinian struggle against Israeli occupation.

Yet, history also teaches us that during political transitions, women are regularly marginalized and tend to lose many of the gains they might have acquired, or have been promised, at the height of a revolutionary struggle. We see this development most clearly in the Egyptian context, where the institutionalization of the various aspects of the protest movement and political representation has not only been male-dominated but has also been controlled by the military. Here the issue is not only the lack or very limited representation of women in crucial transitional bodies, such as the constitutional review committee, but perhaps more significantly, we see women's rights being actively violated and women's and gender-based issues sidelined, occasionally even ridiculed, sometimes by women themselves.

Unfortunately all cross-cultural and historical evidence suggests that unless women explicitly insist on their gender-specific needs, rights and problems, these will be sidelined, ignored and swept under the carpet. I suggest that the failure to stress women's specific demands within the respective wider struggles is a strategic mistake and will lead to history repeating itself.

Ironically, but again not surprisingly, we can see that women and gender issues are taking center stage in the old regimes' attempts to hold on to power and privilege, and in the violent backlash and counter-revolutionary processes we have been witnessing recently. Egyptian women who 
participated in demonstrations during International Women's Day on 8 March 2011 were harassed and accused of taking away attention from the main issues. Some men who attacked the female protesters claimed that they were seeking to destroy Egypt and undermine family values and the sanctity of the family by telling women to desert their husbands. In this instance it was obvious that the men surrounding them were divided into those who are threatened by a women's bloc making their own demands and thereby challenging the prevailing gender order, and those who stood in solidarity with them, recognizing that the women's demands were at the core of their own visions and ideas of a new Egypt.

The treatment of female protesters has taken on very different forms to that of their male counterparts. Harassment and brutalization by the police, the mukhabarat, or secret police, and the army often has sexual connotations for women. Egyptian female protesters have been strip-searched; pictures have been taken while they were without clothes; they have been accused of prostitution and in some cases forced to undergo virginity testing. Yemen's President Ali Abdullah Saleh suggested in April 2011 that antigovernment protesters in the capital Sanaa were in violation of Islamic law because women were not allowed to mix with men. He engaged in smear campaigns on national TV implying that women in pro-change demonstrations were 'loose'.

The heart-wrenching case of Iman al-Obeidy, a Libyan woman from Benghazi who was raped by a group of military men loyal to Qaddafi, is a cruel reminder of the way rape is a commonly used weapon in warfare. Here rape is not only meant to violate and harm an individual woman, but it is a way to humiliate and violate entire communities. What made this case so different from the many others that go unreported is that Iman alObeidy did not allow herself to be silenced by prevailing notions of shame and codes of honor. She went public, enabling the international media to widely circulate images of her anguish and terror. For me personally, most shocking in the scenes we saw broadcasted around the world were the Libyan women working in the hotel who tried to silence her, calling her a traitor and at some point throwing a coat over her face. Those images made crystal clear what we have known for many years but is still painful to watch and experience in practice: sisterhood is not global. It might not even be local. Women do not necessarily act in solidarity with each other, just because they are women.

In those places in which the protests or revolutionary developments have taken a largely militarized form, the gendered outcomes are from the outset problematic. The images of armed men fighting other armed men in 
Libya are a huge cause for concern. Documented cases of female African migrant workers being raped in Tripoli and elsewhere by anti-Qaddafi forces might be individual instances of gender-based violence and human rights violation, however, given the frequently close relationship between the glorification of militarized masculinities and the increase in genderbased violence, I am personally not very optimistic where gender relations in Libya are concerned.

The backlash against women in some current contexts also reminds us that women's reliance on the state to champion and support gender equality and social justice is problematic. It has already become obvious - and I have seen it most clearly in the context of post-invasion developments in Iraq-that politicians and governments in the region have been prone to compromise women's rights in order to shore up support among socially conservative constituencies. In Iraq, for example, the central as well as the Kurdish regional government have been side-lining gender-related issues in the context of negotiating political disputes, such as federalism, regulation of oil and the status of Kirkuk.

Historically, regional women's rights activists have been challenged to not be co-opted by the largely secular authoritarian state's modernizing gender policies and forms of state feminism. When dealing with a dictatorship and a one-party system it is very difficult for women's rights activists to operate independently outside given state structures. Yet, in the past authoritarian regimes have implemented measures to increase gender equality and social justice, as long as these were perceived to be harmless to the regime and the status quo. We have seen this most conspicuously in Tunisia and Iraq, but also to a lesser extent in Egypt, where many women's rights activists collaborated with Suzanne Mubarak's National Union for Women. An exaggerated belief in the ability of the state and the main political party to promote women's rights might seriously diminish women activists' credibility and might limit their strategies and possible achievements in the long run.

Another cause of concern are Islamist constituencies whose gender politics are viewed with great anxiety by secular women and men across the region. At the height of the euphoria in the early phase of the Arab spring, I often argued with Iranian friends whose own revolutionary experiences made them rather sceptical and worried about recent developments in the region. A few months later, there is no doubt that Islamist groups are not only the best organized in terms of political parties but they also appear to be well placed to convince many people that they would provide a viable alternative to the previous secular authoritarian regimes. It is too early to assess their impact on the evolving situation, but it is already evident that 
we have to recognize the variations and range of Islamist groups and their differing gender ideologies and visions. Analytically, it is important to consider the specific historical and current context of specific Islamist parties and groups. Al-Nahda in Tunisia, for example, has, so far, gone out of its way to stress its commitment to women's rights, which is very different from the Muslim Brotherhood in Egypt. But even the Brotherhood appears moderate and favorable in comparison to the Salafis who increasingly claim their space on the political map in Egypt and elsewhere in the region.

Theoretically and politically, several issues emerge from these recent events: the centrality of women and gender when it comes to constructing and controlling communities, be they ethnic, religious or political; the significance of the state in reproducing, maintaining and challenging prevailing gender regimes, ideologies, discourses and relations; the instrumentalization of women's bodies and sexualities in regulating and controlling citizens and members of communities; the prevalence of gender-based violence; the historically and cross-culturally predominant construction of women as second-class citizens; the relationship between militarization and a militarized masculinity that privileges authoritarianism, social hierarchies and tries to marginalize and control not only women but also men, who by virtue of their class, ethnicity, religion, sexuality or politics do not fit into the image of the normative 'ideal man'.

The various theoretical and political issues emerging in relation to recent processes and events in the Middle East illustrate what many of us have been narrating, documenting and analyzing over the past decades but what often remains misunderstood: A gendered lens is not just about women, even though in some contexts that continues to be an important and necessary focus of inquiry, as women are still systematically absent from official accounts, analyses and projected future scenarios. Yet zooming in on what happens to and is going on with femininities, masculinities and sexualities; to gender norms, ideologies and discourses as well as gender roles and relations and the various processes of gendering within all aspects of social, cultural, political and economic lives tells us a great deal about the nature of and dynamics within the state, citizenship, civil society, the military, the economy, etc. When Cynthia Enloe famously and provocatively asked a few years ago whether gender might be the bigger picture, she was alluding to the way we can learn from a gendered lens about power, both the more oppressive top-down variety, but also the more subtle micro-politics of power; and we can learn about hierarchies and inequalities. A gendered lens also allows us to explore the various ways subjects are materially and discursively constituted and circumscribed, both at local and global levels. 